\title{
Regulators of Salmonella-host interaction identified by peripheral blood transcriptome profiling: roles of TGFB1 and TRP53 in intracellular Salmonella replication in pigs
}

\author{
Tinghua Huang, Xiali Huang, Bomei Shi, Fangfang Wang, Wenzhao Feng and Min Yao * (]
}

\begin{abstract}
Peripheral blood transcriptome is an important intermediate data source for investigating the mechanism of Salmonella invasion, proliferation, and transmission. We challenged 4-week old piglets with Salmonella enterica serovar Typhimurium LT2 and investigated the peripheral blood gene expression profile before treatment (d0) and at 2 and 7 days post-inoculation (dpi) using deep sequencing. Regulator pathways were first predicted in silico and validated by wet-lab experiments. In total, 1255, 765, and 853 genes were differentially expressed between $2 \mathrm{dpi} / \mathrm{d} 0,7 \mathrm{dpi} / \mathrm{d} 0$, and $7 \mathrm{dpi} / 2 \mathrm{dpi}$, respectively. Additionally, 1333 genes showed a time effect during the investigated Salmonella infection period. Clustering analysis showed that the differentially expressed genes fell into six distinct expression clusters. Pathway annotation of these gene clusters showed that the innate immune system was first significantly upregulated at $2 \mathrm{dpi}$ and then attenuated at $7 \mathrm{dpi}$. Toll-like receptor cascades, MyD88 cascade, phagosome pathway, cytokine signaling pathway, and lysosome pathway showed a similar expression pattern. Interestingly, we found that the ribosome pathway was significantly inhibited at 2 and $7 \mathrm{dpi}$. Gene expression regulation network enrichment analysis identified several candidate factors controlling the expression clusters. Further in vitro study showed that TGFB1 can inhibit Salmonella replication whereas TRP53 can promote Salmonella replication in porcine peripheral blood mononuclear cells and murine macrophages. These results provide new insights into the molecular mechanism of Salmonella-host interactions and clues for the genetic improvement of Salmonella infection resistance in pigs.
\end{abstract}

\section{Introduction}

Salmonella enterica is a Gram-negative intracellular bacterium with more than 2500 serotypes. Serovars such as Typhimurium and Choleraesuis that colonize both animals and humans are of public health importance [1]. In pigs, Salmonella enterica is the cause of asymptomatic carriage status to systemic febrile infection-related death varying with the ages of the animals [2]. Salmonella carrier pigs can transmit bacteria to other animals raised in the same pen or may contaminate the pig carcass in the slaughterhouse, thus posing a significant threat to the swine industry [3]. Establishment of carrier status

*Correspondence: minyao01@126.com

College of Animal Science, Yangtze University, Jingzhou 434025, Hubei, China is determined by the pathogenicity of serovars causing the infection as well as the genetic predisposition of the infected individual [4]. Several important Salmonella resistance genes have been identified in animals including SLC11A1 [5], TLR4 [6], LBP, and CD14 [7], NADPH oxidase and NOS2 [8], TNF and IFNG $[9,10]$, IL12 [11], TGFB1 [12], TRP53 [13], and more remaining to be discovered. The TGFB1 gene encodes a secreted ligand of the TGF-beta superfamily, binds various TGF-beta receptors that regulate gene expression, cell proliferation, differentiation and growth, and can modulate expression and activation of other growth factors including IFNG and TNF $[9,10]$. The TRP53 gene encodes tumor protein p53, which responds to diverse cellular stresses to regulate target genes that induce cell cycle arrest, apoptosis,

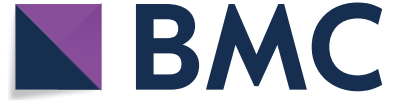

(c) The Author(s) 2018. This article is distributed under the terms of the Creative Commons Attribution 4.0 International License (http://creativecommons.org/licenses/by/4.0/), which permits unrestricted use, distribution, and reproduction in any medium, provided you give appropriate credit to the original author(s) and the source, provide a link to the Creative Commons license, and indicate if changes were made. The Creative Commons Public Domain Dedication waiver (http://creativecommons.org/ publicdomain/zero/1.0/) applies to the data made available in this article, unless otherwise stated. 
senescence, DNA repair, or changes in metabolism [14, 15].

An alternative approach for identifying the key genes controlling Salmonella infection is to measure host responses to Salmonella [16-20], and screening the host mRNA responses [21] in immune tissues such as the lungs, Peyer's patches, or lymph nodes using real-time PCR [22] or microarrays [23-25]. Evidence from systemic typhoid infections indicate that some of the ingested bacteria invade epithelial and $M$ cells, and are engulfed by resident macrophages in the submucosa $[26,27]$. Casp1mediated macrophage death and escape of bacteria from the intracellular environment allows further systemic dissemination of Salmonella to the bloodstream either by entering the blood directly or by passing through lymphatic vessels and mesenteric lymph nodes [28]. In the blood stream, bacteria transport to distant sites to reach an intracellular location in the liver, spleen, or bone marrow $[28,29]$. In these processes, the blood stream is an important inter-medium window for Salmonella invasion, transportation, and proliferation, to finally exert its virulence. To date, there have been many reports on the responses of the transcriptome in porcine whole blood or peripheral blood derived cell populations to infection with bacteria or viruses $[25,30-36]$, immune stimulants [37], or following vaccination [38]. Several reports have demonstrated the genetic control of various immune cell parameters or immunological traits [39-44], as well as loci associated with susceptibility to salmonellosis [45, 46].

The peripheral blood transcriptome may be reflected in the gene expression response to Salmonella inoculation from early invasion to late carrier establishing stages. Therefore, studies have been performed on 40 piglets to determine the spectrum of transcriptional regulation by Salmonella enterica serovar Typhimurium inoculation $[25,47]$. Two groups of pigs with either low shedding (LS) or persistent shedding (PS) phenotypes were identified. Global transcriptional changes in response to Salmonella inoculation were investigated using Affymetrix Genechip ${ }^{\circledR}$ analysis of peripheral blood RNA at d0 and 2 dpi. Salmonella inoculation triggered substantial gene expression changes in the pigs and 217 genes were differentially expressed between LS and PS pigs. Analysis of the differential gene expression profiles revealed distinct regulatory pathways mediated by IFN- $\gamma$, TNF, and NF-кB. These data provided useful information on the early immune response to Salmonella infection in pigs, however, the later stages remain unknown.

In the current study, we challenged piglets with Salmonella enterica serovar Typhimurium LT2, a genome sequencing completed Salmonella serovars, and investigated the gene expression profile in peripheral blood at d0, 2 dpi, and 7 dpi using deep sequencing technology. We identified two novel regulatory genes that downregulate host genes. Further studies indicated that these two genes play roles in regulating intracellular Salmonella replication in porcine PBMCs and murine macrophage cells. This study provides new data on peripheral blood transcriptomic responses to Salmonella enterica serovar Typhimurium challenge in piglets and reveals the regulatory pathways and key genes controlling these gene expression responses. These genes can be targeted for further exploration on the development of carrier status. This knowledge can also be used for rational manipulation of genetics, pharmaceuticals, and nutrition or husbandry methods to decrease Salmonella colonization, shedding, and spread.

\section{Materials and methods}

\section{Animal challenge, sample collection, and processing}

Peripheral blood samples were collected from 30 piglets (bought from a commercial swine farm) challenged with Salmonella enterica serovar Typhimurium LT2 using a previously described method [47]. In brief, piglets of the Duroc $\times$ Landrace $\times$ Yorkshire crossbreed were used. Piglets were raised in fully enclosed climate-controlled isolation facilities. The pig fecal matter tested negative for Salmonella three times before intranasal challenge with $10^{9}$ colony forming units (cfu) of Salmonella enterica serovar Typhimurium LT2 at 4 weeks of age. Blood samples were collected from each animal at $\mathrm{d} 0$ or at 2 and 7 dpi (10 animals per group). Peripheral whole blood (approximately $2.3 \mathrm{~mL}$ ) was collected from the jugular vein into PAXgene Blood RNA tubes and processed according to the instructions provided by Qiagen. Total RNA for all animals was prepared from 4.5 to $9.0 \mathrm{~mL}$ solutions from the PAXgene Blood RNA tubes using the PAXgene Blood RNA kit (Qiagen, Cat. no. 762164). The quantity and quality of RNA samples were determined using the Agilent 2100 Bioanalyzer (Agilent Technologies, Santa Clara, CA, USA) and Nanodrop 2000 (Thermo Scientific, Wilmington, DE, USA). RNA samples with the RIN number lower than 7 or yield less than $3 \mu \mathrm{g}$ were identified as low quality and excluded from the experiment. Four samples from each group (d0 or 2 and 7 dpi) were selected for transcriptome analysis.

\section{Deep sequencing and statistical analysis}

Sequencing libraries were prepared using the Illumina Truseq RNA sample preparation kit according to the manufacturer's protocol (Illumina Inc., USA). Approximately $10 \mu \mathrm{g}$ of total RNA from each sample was used for library construction and RNA sequencing. Sequencing was conducted on an Illumina HiSeq 2000 (Illumina Inc., USA) by single-read sequencing (read length $50 \mathrm{bp}$ ). The 
images generated by the sequencer were converted into raw reads by base calling. Data filtering was conducted to obtain clean reads and to remove low quality reads present in the raw reads. The procedure includes the following steps: 1) Removal of reads in which unknown bases (N) are presented; 2) removal of low quality reads, i.e., if the reads have low quality bases (bases with quality value $\leq 5$ ). Bowtie1 [48] was used to map clean reads to the reference genes set, which was extracted from the NCBI reference sequence database [49]. The calculated reads count per gene per length were used for comparing the difference in gene expression among samples. The limma $\mathrm{R}$ package [50] was used for the calculation and the criteria for differentially expressed genes were controlled as FDR (false discovery rate) $\leq 0.05$ and fold change $\geq 1.5$ or $\leq 0.67$. All the data discussed in this study have been deposited to NCBI GEO database [51] under accession number GSE118150. The fixed effects for time along with random pig effects were fit to the expression data for each gene using SAS PROC MIXED and the p-values for each test were converted to FDR and controlled at $\leq 0.05$ as well [52].

\section{Real-time PCR, ELISA, and functional annotation of differentially expressed genes}

Pig peripheral blood was collected into citrate tubes $(6 \mathrm{~mL})$ from 20 animals and randomly divided into five groups. One group was used as a control and other groups were used in two separate experiments: (1) treated with TGF- $\beta 1$ recombinant protein (240-B-010, R\&D Systems, Inc, MN, USA), or it's inhibitor (Pifithrin- $\alpha$ hydrobromide, R\&D Systems); (2) treated with p53 recombinant protein (SP-454-020, R\&D Systems), or it's inhibitor (SB-431542, R\&D Systems). The samples were incubated for $4 \mathrm{~h}$ at $37{ }^{\circ} \mathrm{C}$ with $5 \% \mathrm{CO}_{2}$ under conditions reported previously for in vitro stimulation of whole blood [53]. RNA samples extracted from the peripheral blood of 20 animals with different treatment were used for real-time PCR. Reverse transcription was performed using SuperScript II Reverse Transcriptase and Oligo(dT) primers according to the manufacturer's instructions (Invitrogen, Carlsbad, CA, USA). Real-time PCR was performed using a standard SYBR Green PCR kit (Applied Biosystems, Carlsbad, CA, USA) and a BIO-RAD iQ5 RealTime PCR Detection System. All reactions were run in duplicate. The data were initially normalized using the averaged expression level of Beta-actin and GAPDH. The serum TGF- $\beta 1$ and $\mathrm{p} 53$ protein levels were quantified using the DuoSet ${ }^{\circledR}$ IC ELISA kit and Quantikine ${ }^{\circledR}$ ELISA, respectively, according to the manufacturer's instructions (R\&D Systems). The most current porcine gene annotation was used to assign the transcripts to mouse RefSeq according to the dual best match method. Cluster and
Treeview softwares were used to cluster the data [54]. The open-access bioinformatics tool, InnateDB [55], was used to identify significantly regulated pathways between different time points and shedding phenotypes. The significantly enriched gene expression regulators of these differentially expressed gene lists were identified by Gene Expression Regulator Enrichment Analysis (GEREA) developed in-house (Additional file 1).

\section{Intracellular Salmonella replication assays}

Salmonella intracellular replication assays were carried out using a previously described protocol $[56,57]$. RAW 264.7 (ATCC $^{\circledR}$ TIB-71 ${ }^{\mathrm{TM}}$ ) cells were cultured in DMEM, supplemented with 10\% FBS and 1\% GlutaMAX (GIBCO) at $37{ }^{\circ} \mathrm{C}$ under $5 \%$ CO2. TGF- $\beta 1$ and $\mathrm{p} 53$ recombinant proteins and inhibitors were incubated with the cells for $24 \mathrm{~h}$ prior to bacterial addition. Bacterial inoculation was carried out by adding $5 \mu \mathrm{L}$ of Salmonella culture, centrifugation, followed by $2 \mathrm{~h}$ of incubation at $37{ }^{\circ} \mathrm{C}$ in a $5 \% \mathrm{CO}_{2}$ atmosphere. The monolayers in microtiter cell plates were washed with PBS and then incubated for another $2 \mathrm{~h}$ in fresh media containing $100 \mu \mathrm{g} / \mathrm{mL}$ of gentamicin. This treatment kills the extracellular bacteria but does not affect the viability of intracellular organisms [57]. Monolayers were washed three times with PBS, and $0.2 \mathrm{~mL}$ of $1 \%$ Triton X-100 solution was added. This was followed by a 5 -min incubation period to release the intracellular bacteria. L-broth was added, appropriate dilutions were spread onto L-agar plates, and bacterial counts were determined. The experiment was repeated three times.

\section{Results}

\section{Gene expression changes in peripheral blood}

following challenge with Salmonella enterica serovar Typhimurium

Our previous investigations have demonstrated that the peak of both clinical symptoms (fever, diarrhea, decreased appetite) as well as Salmonella shedding occurs at $2 \mathrm{dpi}$ and is attenuated at $7 \mathrm{dpi}[25,47]$. Thus, the peripheral blood RNA expression data for $\mathrm{d} 0,2 \mathrm{dpi}$, and $7 \mathrm{dpi}$ were profiled and the resulting data were analyzed as described in the Methods section. The complete data on gene expression are shown in Additional file 2. Direct comparison between different time points revealed 1095 transcripts that were differentially expressed between 2 dpi and d0 and 595 transcripts differentially expressed between $7 \mathrm{dpi}$ and d0 after Salmonella enterica serovar Typhimurium inoculation. We also observed 452 transcripts differentially expressed between $7 \mathrm{dpi}$ and $2 \mathrm{dpi}$. In total, 480 transcripts were statistically significant $(F D R<0.05)$ for tests of time effects. The numbers of differentially expressed transcripts (NCBI 
Reference Sequence) for each comparison, and the numbers of transcripts overlapping among comparisons (comparing $2 \mathrm{dpi} / \mathrm{d} 0,7 \mathrm{dpi} / \mathrm{d} 0$, or $7 \mathrm{dpi} / 2 \mathrm{dpi}$ ), are shown in Figure 1A, full lists are available in Additional file 3. As expected, we observed significant variation in the RNA levels for 53 genes responding to IFN- $\gamma$ stimulation [58], including Casp1, CASP4, CD14, CEBPB, IRF3, SLC11A1, SPI1, and TLR4, along with 55 genes responding to TNF stimulation [58], including MAPK14, TLR4, CASP1, CD47, CEBPB, CSF2RB, GADD45B, and others. The mRNA levels for innate inflammatory marker genes such as SLC11A1 and TLR4 were strongly changed following Salmonella inoculation. Comparison with differentially expressed gene counts in peripheral blood after Salmonella inoculation in pigs as reported by Huang et al. [25] revealed a total of 13 genes in common with LS animals, 666 genes in common with PS animals, and 80 genes in common upon PS/LS comparison (Figure 1B). Interestingly, we found a total of 775 genes that were differentially expressed in piglets challenged with Salmonella enterica serovar Typhimurium LT2, which were unique to LS and PS animals.

\section{Distinctive mRNA expression patterns during Salmonella enterica serovar Typhimurium challenge in peripheral blood}

To visually illustrate the expression type of mRNAs being expressed during Salmonella enterica serovar Typhimurium challenge in peripheral blood, hierarchical cluster analysis was performed for the genes differentially expressed between $2 \mathrm{dpi} / \mathrm{d} 0,7 \mathrm{dpi} / \mathrm{d} 0,7 \mathrm{dpi} / 2 \mathrm{dpi}$, and genes showing time effects. The results showed that the mRNA expression patterns fall into six typical categories: (A) activated at $2 \mathrm{dpi}$, expression level increased between $2 \mathrm{dpi}$ and $\mathrm{d} 0$ and then moderately expressed at $7 \mathrm{dpi}$; (B) activated at $7 \mathrm{dpi}$, low expressed at $\mathrm{d} 0$, expression level increased at $7 \mathrm{dpi}$; (C) activated at $2 \mathrm{dpi}$ and dropped at 7 $\mathrm{dpi}$, expression level increased between $2 \mathrm{dpi}$ and $\mathrm{d} 0$ and then decreased at $7 \mathrm{dpi}$; (D) down-regulated at both $2 \mathrm{dpi}$ and $7 \mathrm{dpi}$, expression levels lower at both $2 \mathrm{dpi}$ and $7 \mathrm{dpi}$ compared with d0; (E) downregulated at 2 dpi and upregulated at $7 \mathrm{dpi}$, expression levels are significantly lower at 2 dpi and higher at 7 dpi compared with d0; (F) downregulated at $2 \mathrm{dpi}$ and attenuated at $7 \mathrm{dpi}$, the expression levels are significantly lower at $2 \mathrm{dpi}$ compared with $\mathrm{d} 0$ with moderate expression at $7 \mathrm{dpi}$. The expression patterns described above are clearly reflected by the formation of several large clusters in the tree map of the clustering results (Figure 2).

\section{Functional annotation of genes showing similar expression pattern}

Pathway annotation of the six gene clusters showed that the innate immune system, Toll-like receptors cascades, MyD88 cascade, phagosome and lysosome pathway, cytokine signaling pathway, and lysosome pathway were over-represented in Cluster A. In total, 55 immune genes were presented in Cluster A wherein 27 were related to the innate immune system and 23 were related to the adaptive immune system. We also found 16 phagosome genes and 15 lysosome genes in Cluster A. In total, 8.6\% genes in Toll-like receptors cascades are presented in

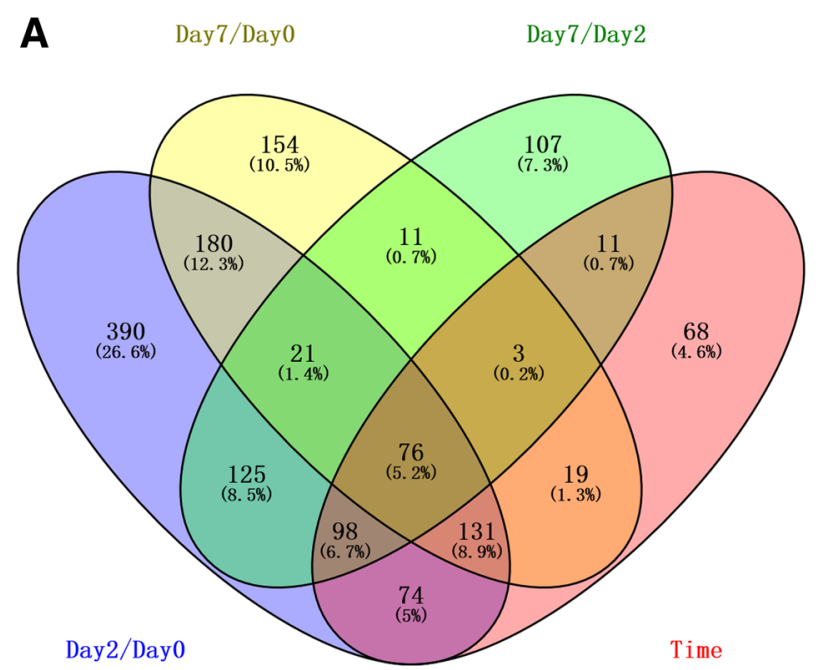

B LS Day2

PS Day2/Day0

Figure 1 Numbers of differentially expressed genes. A Summary of differentially expressed transcripts responding to Salmonella inoculation (2 $\mathrm{dpi} / \mathrm{d} 0,7 \mathrm{dpi} / \mathrm{d} 0,7 \mathrm{dpi} / 2 \mathrm{dpi}$, or expression showing time effect. B Comparison of differentially expressed gene counts in LS/PS animals as reported by Huang et al. [25]. These genes were identified using the linear mixed model, and the false discovery rate (FDR) was controlled at less than 0.05 , with the fold change between time points required to be higher than 1.5 or less than 0.67 . 


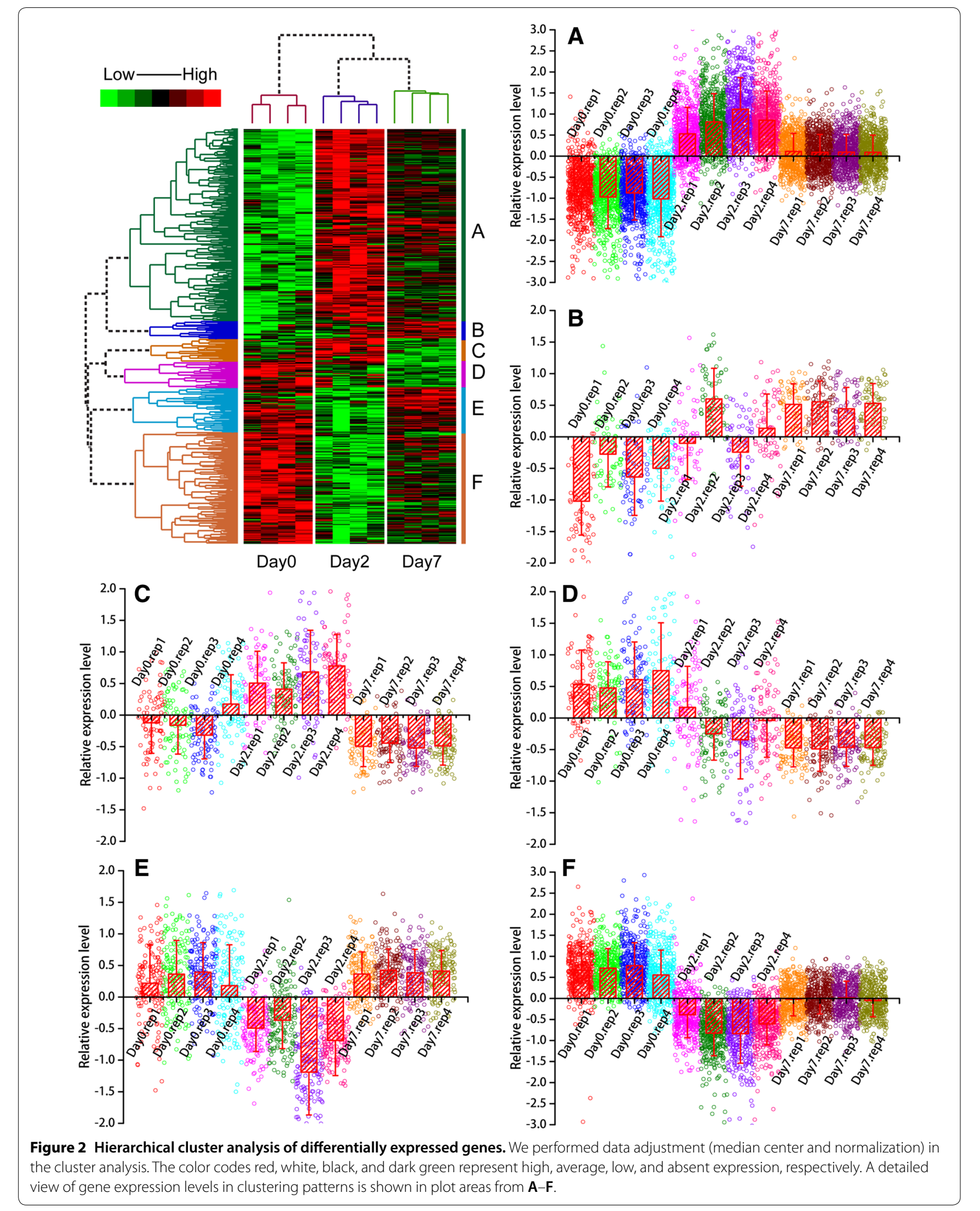


Cluster A and 10 of these are involved in the TLR4 cascade. The cytokine signaling system was also significantly over-represented in Cluster A. In Cluster B, there were no significantly over-represented pathways. In Cluster $\mathrm{C}$, metabolism and disease pathways were significantly over-represented. In Cluster D, cell cycle-related pathways were over-represented, 8 genes were related to the mitotic pathway and 6 genes were related to the G1 - G1/S phases. In Cluster E, genes related to expression were over-represented. More specifically, 9 genes were related to translation pathways and 8 genes were from the eukaryotic translation initiation, elongation and termination pathway. Cluster $\mathrm{F}$ was also related to expression. In this cluster, 15 genes were involved in the translation pathway, 14 genes were related to ribosome; more specifically, 13 genes were related to translation elongation, 13 genes were related to translation initiation, and 12 genes were related to translation termination. The significantly over-represented pathways in cluster A, C, $\mathrm{D}, \mathrm{E}$, and $\mathrm{F}$ are listed in Additional file 4.

Using regulator-target relationships known from PubMed literature, we used Gene Expression Regulator Enrichment Analysis (GEREA) to identify key "regulators" whose connections to specific sets of differentially expressed target genes were over-represented $(\mathrm{FDR}<0.05$, Figure 3 and Table 1$)$. Such relationships include direct interactions as well as more indirect relationships inferred from published sources. Very few common regulators of target genes were significantly over-represented in the lists of Cluster B and C. However, in Cluster A, many regulator-target relationships were statistically significant, including cytokines such as TNF, IFN- $\gamma$, and immune-inflammatory-related transcription factors such as MAPK14 and STAT3, which were linked to the largest number of differentially expressed genes, indicating their important roles in the regulation of gene expression responses to Salmonella enterica serovar Typhimurium infection. Four interleukins (IL1$\beta$, IL6, IL4, and IL13) were also significantly enriched. These interleukins have extensive effects on $\mathrm{T}$ cell activation, $B$ cell proliferation, natural killer cell activation, and antibody production, and also have broad interactions with other immune and inflammatory modulators such as IFN- $\gamma$ and NF- $\kappa B$. Several other genes with altered expression patterns following Salmonella inoculation, including IRFs and STATs, as well as SPI1, and TLR4, showed significantly enriched regulator-target sets. The regulator of TGFB1, whose protein product acts as transforming growth factor, was also significantly enriched with a high number of target genes. The full list of regulators is available in Additional file 5.

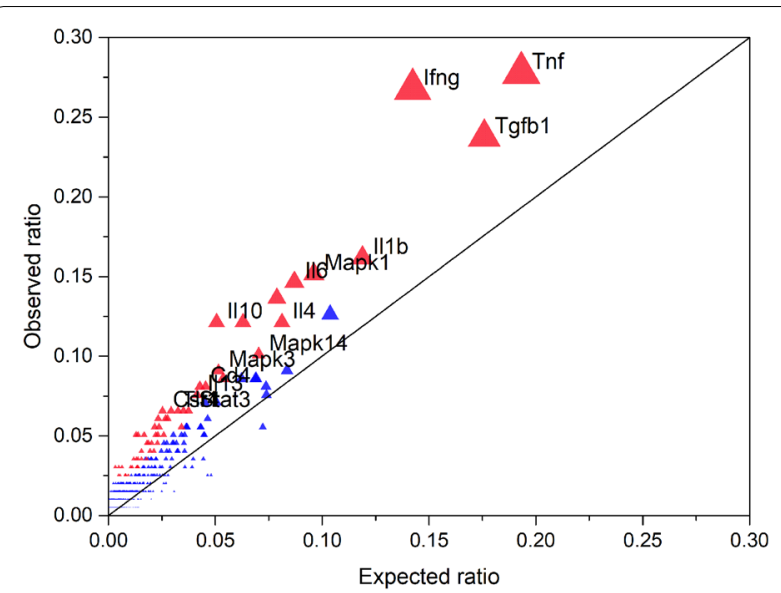

Figure 3 Gene expression regulator enrichment analysis using the genes in Cluster A. The significantly over-represented regulators were plotted based on the ratio of targets to the total number of transcripts in the differentially expressed gene list (observed) and all genes presented in the transcriptome (expected). Red color indicates that the regulator is statistically significant whereas blue indicates no significance. The size of the triangle indicates the number of targets for the regulator.

In Cluster $\mathrm{D}$, nine regulator-target relationships were statistically significant, including EGF, which is implicated in cell proliferation and differentiation, MAPK1 that is involved in a wide variety of cellular processes such as proliferation, differentiation, transcription regulation, and development, and TRP53 that responds to diverse cellular stresses to regulate target genes that induce cell cycle arrest and apoptosis (Table 1). In Cluster E, a total of 20 regulator-target relationships were statistically significant including TNF, TGFB1, FGF2, IL4, and CREB1 (Table 1). Some of these regulators such as TNF and TGFB1, were also statistically significant in Cluster A. As the regulation relationships from the regulator to the targets include both direct interactions as well as more indirect relationships, Salmonella may target downstream hubs of these regulators and inhibit a sub-network. In Cluster F, TRP53, MAPK14, CD8A, and GATA1 were statistically significant, whereas TRP53 regulated the largest number of target genes (Table 1). TRP53 encodes the tumor suppressor protein p53, which responds to diverse cellular stresses to regulate target genes that induce cell cycle arrest and apoptosis. Interestingly, the cell cycle-related pathways were downregulated at both $2 \mathrm{dpi}$ and $7 \mathrm{dpi}$ (over-represented in Cluster D), suggesting that TRP53 may be an important target of Salmonella. The relevant functions of other over-represented 
Table 1 Significantly over-represented regulators in clusters D, E, and F

\begin{tabular}{|c|c|c|c|c|c|c|}
\hline Cluster name & Pathway regulator & $\begin{array}{l}\text { Gene count } \\
\text { in pathway }\end{array}$ & $\begin{array}{l}\text { Gene count } \\
\text { in cluster }\end{array}$ & $\mathrm{PO}^{\mathrm{a}}$ & $P 1^{b}$ & $\mathrm{FDR}^{\mathrm{c}}$ \\
\hline Cluster D & Egf & 459 & 8 & 0.084 & 0.364 & 0.000 \\
\hline Cluster D & Mapk1 & 528 & 6 & 0.096 & 0.273 & 0.013 \\
\hline Cluster D & Ppara & 255 & 5 & 0.046 & 0.227 & 0.003 \\
\hline Cluster D & Mapk3 & 283 & 5 & 0.052 & 0.227 & 0.004 \\
\hline Cluster D & Lep & 295 & 5 & 0.054 & 0.227 & 0.005 \\
\hline Cluster D & Mapk14 & 386 & 5 & 0.070 & 0.227 & 0.014 \\
\hline Cluster D & Trp53 & 405 & 5 & 0.074 & 0.227 & 0.016 \\
\hline Cluster D & $\| 4$ & 446 & 5 & 0.081 & 0.227 & 0.025 \\
\hline Cluster D & 116 & 478 & 5 & 0.087 & 0.227 & 0.031 \\
\hline Cluster E & Tnf & 1061 & 17 & 0.193 & 0.370 & 0.003 \\
\hline Cluster E & Tgfb1 & 966 & 15 & 0.176 & 0.326 & 0.007 \\
\hline Cluster E & Fgf2 & 397 & 8 & 0.072 & 0.174 & 0.015 \\
\hline Cluster E & $\| 4$ & 446 & 8 & 0.081 & 0.174 & 0.024 \\
\hline Cluster E & Creb1 & 247 & 7 & 0.045 & 0.152 & 0.005 \\
\hline Cluster E & Bdnf & 123 & 6 & 0.022 & 0.130 & 0.001 \\
\hline Cluster E & Ifnb1 & 168 & 6 & 0.031 & 0.130 & 0.003 \\
\hline Cluster E & Cd8a & 159 & 6 & 0.029 & 0.130 & 0.003 \\
\hline Cluster E & $\mathrm{Hgf}$ & 237 & 6 & 0.043 & 0.130 & 0.013 \\
\hline Cluster E & 112 & 245 & 6 & 0.045 & 0.130 & 0.015 \\
\hline Cluster E & Notch1 & 255 & 6 & 0.046 & 0.130 & 0.016 \\
\hline Cluster E & Csf2 & 249 & 6 & 0.045 & 0.130 & 0.019 \\
\hline Cluster E & Sirt1 & 89 & 5 & 0.016 & 0.109 & 0.001 \\
\hline Cluster E & Pten & 102 & 5 & 0.019 & 0.109 & 0.002 \\
\hline Cluster E & Csf3 & 127 & 5 & 0.023 & 0.109 & 0.005 \\
\hline Cluster E & SrC & 188 & 5 & 0.034 & 0.109 & 0.017 \\
\hline Cluster E & Edn1 & 188 & 5 & 0.034 & 0.109 & 0.021 \\
\hline Cluster E & Egfr & 218 & 5 & 0.040 & 0.109 & 0.034 \\
\hline Cluster E & Bmp4 & 197 & 5 & 0.036 & 0.109 & 0.035 \\
\hline Cluster E & Vegfa & 250 & 5 & 0.046 & 0.109 & 0.043 \\
\hline Cluster F & Trp53 & 405 & 14 & 0.074 & 0.128 & 0.017 \\
\hline Cluster F & Mapk14 & 386 & 13 & 0.070 & 0.119 & 0.027 \\
\hline Cluster F & Cd8a & 159 & 7 & 0.029 & 0.064 & 0.047 \\
\hline Cluster F & Gata1 & 88 & 5 & 0.016 & 0.046 & 0.031 \\
\hline
\end{tabular}

${ }^{a}$ An expected ratio in the background.

b An observed ratio in the list of differentially expressed gene.

c Statistical analysis was performed based on cumulative hypergeometric distribution and corrected by Benjamini and Hochberg method.

regulators and subnetworks of regulated targets are less defined.

\section{TNF- $a$, IFN- $\gamma$, TGFB1, and TRP53 profiles in Salmonella challenged pigs}

We measured the serum concentrations of top enriched gene expression regulators in Cluster A (TNF- $\alpha$, IFN- $\gamma$, TGF- $\beta 1$ ), and in Cluster F (p53) as biomarkers of inflammation and gene expression regulation to identify the potential response differences introduced by Salmonella challenge (Figure 4). Prior to challenge, serum samples from the 30 pigs presented similar concentrations of these proteins when compared to control pigs (d0). However, at $2 \mathrm{dpi}$, distinct differences emerged in pigs compared to those at $\mathrm{d} 0$. The serum collected at $2 \mathrm{dpi}$ from pigs showed elevated TNF- $\alpha$, IFN- $\gamma$, TGF- $\beta 1$, and p53 concentrations compared to those at $\mathrm{d} 0(p \leq 0.05)$. Pigs at 7 dpi showed decreased concentrations of TNF- $\alpha$ and TGF- $\beta 1$ compared with those at 2 dpi $(p \leq 0.05)$, but still higher than those at $\mathrm{d} 0$. IFN- $\gamma$ concentrations were lower at $7 \mathrm{dpi}$ than at $2 \mathrm{dpi}$, but were still significantly higher than those at $\mathrm{d} 0(p \leq 0.05)$. The concentrations of TRP53 

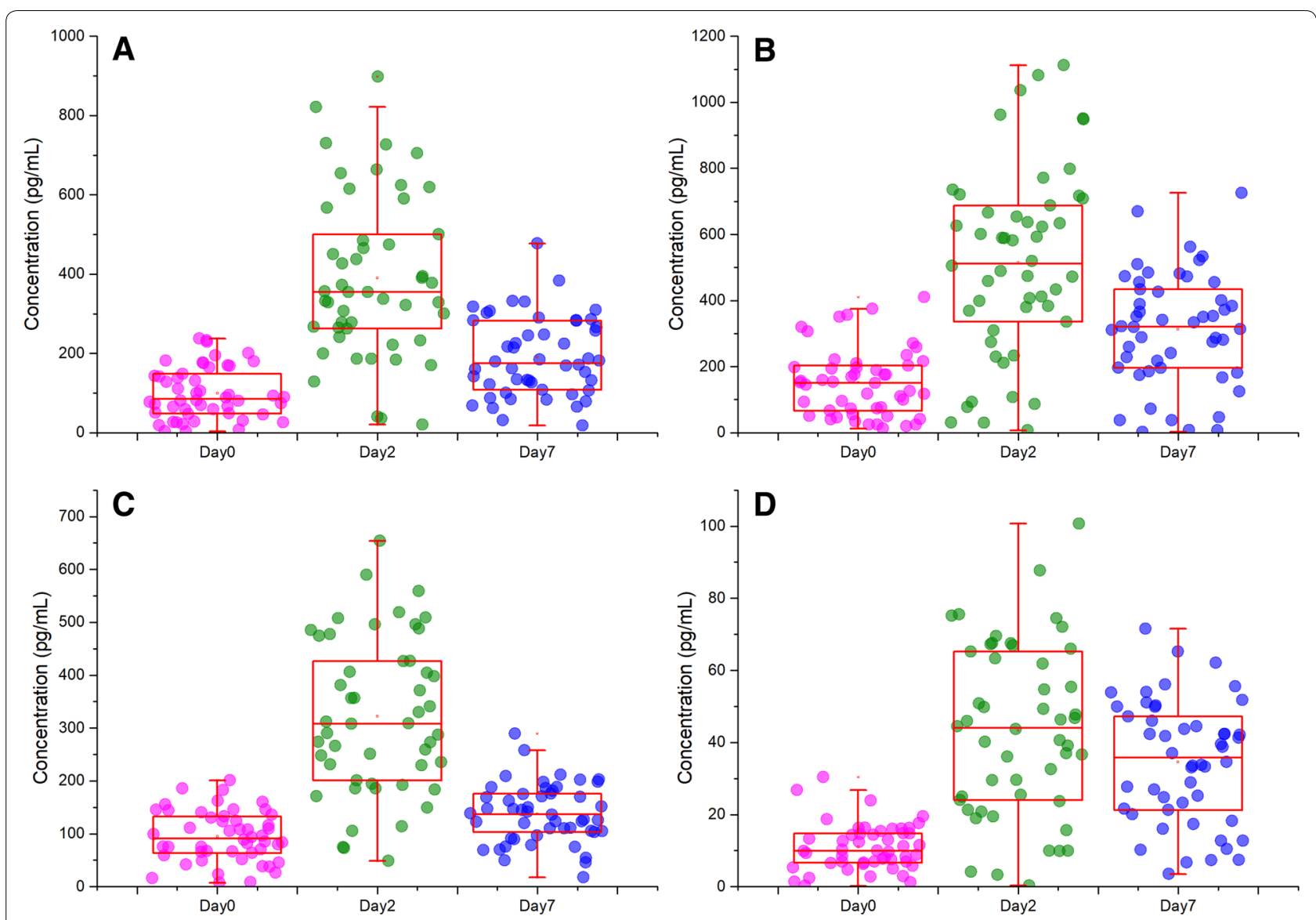

Figure 4 Peripheral blood concentrations in Salmonella-challenged pigs. Serum protein levels were measured prior to challenge and at 2 and 7 dpi using ELISA. Results are presented as box plots plus scatter plots for each sample. Plots A-D show the results of TNF-a, IFN- $\gamma$, TGFB1, and TRP53 respectively.

remained elevated at $7 \mathrm{dpi}$ (not significant compared to 2 dpi) and were four folder higher than those at d0.

\section{Expression of target genes in response to in vitro treatment with TGF- $\beta 1$ and $\mathrm{p} 53$}

To determine if the in vivo expression patterns of target genes of two of the top enriched gene expression regulators, TGFB1 and TRP53, could be regulated by recombinant proteins as well as protein inhibitor treatment, we used real-time PCR after in vitro treatment with two different doses of recombinant proteins $(1 \mathrm{ng} / \mathrm{mL}$ and $10 \mathrm{ng} /$ $\mathrm{mL})$ and TGFB1 and TRP53 inhibitors $(0.1 \mu \mathrm{mol} / \mathrm{mL}$ and $0.5 \mu \mathrm{mol} / \mathrm{mL}$ ). Samples were collected at $4 \mathrm{~h}$ post-stimulation and subjected to real-time PCR using the primers listed in Additional file 6. In total, 28 randomly selected target genes (14 for each) were selected for measurement. Thirteen out of 14 TGFB1 targets showed upregulation upon treatment with $1 \mathrm{ng} / \mathrm{mL}$ recombinant protein. All 14 TGFB1 targets were upregulated when treated with
$10 \mathrm{ng} / \mathrm{mL}$ recombinant protein. When TGFB1 inhibitor was added, the target genes showed no response at all. Four out of 14 TRP53 targets were downregulated when treated with $1 \mathrm{ng} / \mathrm{mL}$ recombinant protein. Thirteen out of 14 TRP53 targets showed downregulation when treated with $10 \mathrm{ng} / \mathrm{mL}$ recombinant protein. When TRP53 inhibitor was added, the target genes showed no response at all. The raw data and statistical results for real-time PCR are shown in Additional file 7.

To determining whether the treatment response pattern of combined target genes was similar or different to the patterns detected upon in vivo Salmonella challenge, hierarchical cluster analysis of the average mRNA levels of 28 target genes was performed. The results indicated that the expression patterns of samples treated with recombinant TGF- $\beta 1$ protein were clustered with the 2 dpi Salmonella challenge group. The before treatment group and TGFB1 inhibitor treatment group were mixed up with the 0 dpi and 7 dpi Salmonella challenged groups. No dose effect of recombinant TGF- $\beta 1$ protein 
and its inhibitor was observed as the $1 \mathrm{ng} / \mathrm{mL}$ TGF- $\beta 1$ group was clustered together with the $10 \mathrm{mg} / \mathrm{mL}$ TGF$\beta 1$ group and the $0.1 \mu \mathrm{mol} / \mathrm{mL}$ inhibitor group was clustered together with the $0.5 \mu \mathrm{mol} / \mathrm{mL}$ inhibitor group in the tree map. The most similar pattern seen upon recombinant p53 protein treatment was in the $2 \mathrm{dpi}$ and $7 \mathrm{dpi}$ Salmonella challenge group. The recombinant p53 protein treatment group was most similar to the $2 \mathrm{dpi}$ Salmonella challenged group, whereas the TRP53 inhibitor treatment group was clustered together with the $7 \mathrm{dpi}$ Salmonella challenged group as well as the before treatment and challenge group. The cluster result of TGFB1 is shown in Figure 5A and that for TRP53 is showed in Figure 5B.

TGFB1 and TRP53 regulate intracellular Salmonella growth PBMCs were first treated with recombinant TGFB1, recombinant TRP53, or their inhibitors and were then treated with Salmonella to examine how two genes would affect the intracellular Salmonella growth (Additional file 8). The results showed that after treatment with recombinant TGFB1, the intracellular bacteria in PBMCs were significantly lower at 12 and $24 \mathrm{~h}$ posttreatment compared to the results obtained in the control experiment $(p<0.05$, Figure $6 \mathrm{~A})$. The intracellular bacterial growth in PBMCs was continually increased over time in cells treated with the TGFB1 inhibitor, and was significantly higher at 12 and 24 h post-treatment than in the control experiment. In murine macrophages (raw 264.7), intracellular bacterial growth is similar to that within PBMCs as recombinant TGFB1 treatment decreased the intracellular bacterial growth whereas the inhibitor increased bacterial growth. Treatment of PBMCs with TRP53 inhibitor had no effect on intracellular bacterial growth (there was no difference between TRP53 inhibitor treatment and the control experiment). However, after treatment with the recombinant p53 protein, intracellular bacterial growth was significantly higher at 4,12 , and $24 \mathrm{~h}$ post-treatment compared with the TRP53 inhibitor treatment and the control experiment $(p<0.05$, Figure $6 \mathrm{C})$. In murine macrophages, the effect of recombinant TRP53 and TRP53 inhibitor treatment is clear, wherein treatment with recombinant p53 protein increased the intracellular bacterial growth at 12 and $24 \mathrm{~h}$ post-treatment and treatment with the TRP53 inhibitor decreased the intracellular bacterial growth at 12 and 24 h post-treatment $(p<0.05$, Figure 6D).

\section{Discussion}

\section{Peripheral blood transcriptome activation associated with Salmonella Typhimurium challenge}

The genes responding to Salmonella challenge at 2 and 7 dpi indicated that the innate immune genes constituted the majority of over-represented responses and this was confirmed by InnateDB and GEREA analysis. InnateDB over-representation analysis identified that the TLR4 and IFN- $\gamma$ systems are major inducers of transcriptomic responses in the peripheral blood of pigs. Significant upregulation of mRNA for TLR4 and elevation of over 9.2\% genes in the TLR signaling pathway at $2 \mathrm{dpi}$ indicated that this pathway was extensively activated at an early stage in response to Salmonella. The activated downstream cascades of the cytokine signaling pathway, Myd88 cascade, IFN $-\gamma$ cascade, phagosomes, and lysosomes together with the Toll-like receptor signaling pathway itself cover most of the over-represented pathways, further indicating primary roles for TLR4 and IFN- $\gamma$ systems in this response. GEREA analysis confirmed the importance of TLR4 and IFN- $\gamma$, and also identified other important regulators such as TNF (highest numbers of differentially expressed gene connected to this regulator), MAPKs (Mapk1, Mapk3, and Mapk14), and interleukins IL1 $\beta$, IL6, IL4, and IL13.

Most importantly, the serum protein level of IFN- $\gamma$ and TNF, the top ranked regulator for the differentially expressed genes in Cluster A (cluster with largest numbers of genes), was increased after Salmonella inoculation. IFN- $\gamma$, produced predominantly by $\mathrm{T}$ lymphocytes and natural killer cells [59], is believed to prime macrophages to respond more vigorously to LPS. IFN- $\gamma$ signaling also induces expression of several TLR signaling components including TLR4, which was differentially expressed in pig peripheral blood in response to Salmonella inoculation ( 13 fold for $2 \mathrm{dpi} / \mathrm{d} 0$, sixfold for $7 \mathrm{dpi} /$ $\mathrm{d} 0,0.5$ fold for $7 \mathrm{dpi} / 2 \mathrm{dpi}$ ), and has been proposed to remodel the initial NF- $\kappa B$ signaling [59]. TNF is a pleiotropic pro-inflammatory cytokine produced mainly by macrophages but also by activated NK cells and Th1 lymphocytes [9]. TNF plays a key role in the host defense against pathogens through several mechanisms including activation of neutrophils and platelets, enhancement of the killing activity of macrophages and NK cells, and activation of the immune system. It is encoded by the TNF gene and exerts its effects through two types of receptors, the TNFRP55 (encoded by TNFRSF1A, TNF receptor superfamily $1 \mathrm{~A}$ gene) and TNFRP75 (TNFRSF1B). The early phase of bacterial killing within the macrophages is associated with activation of the NADPH oxidase system and the TNF receptor, TNFRP55 is necessary for targeting NADPH phagocyte oxidase-harboring vesicles to SCVs (Salmonella containing vacuoles) [60]. The upregulation of IFN- $\gamma$ and TNF in serum and their roles in gene regulation indicate their important roles in Salmonella infection in pig. 
A

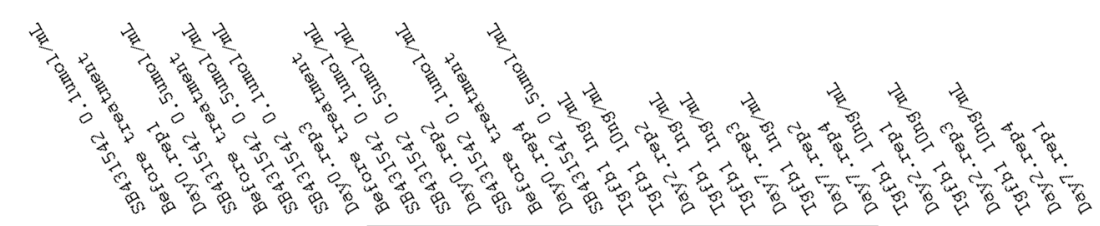

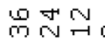

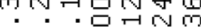

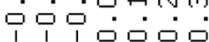
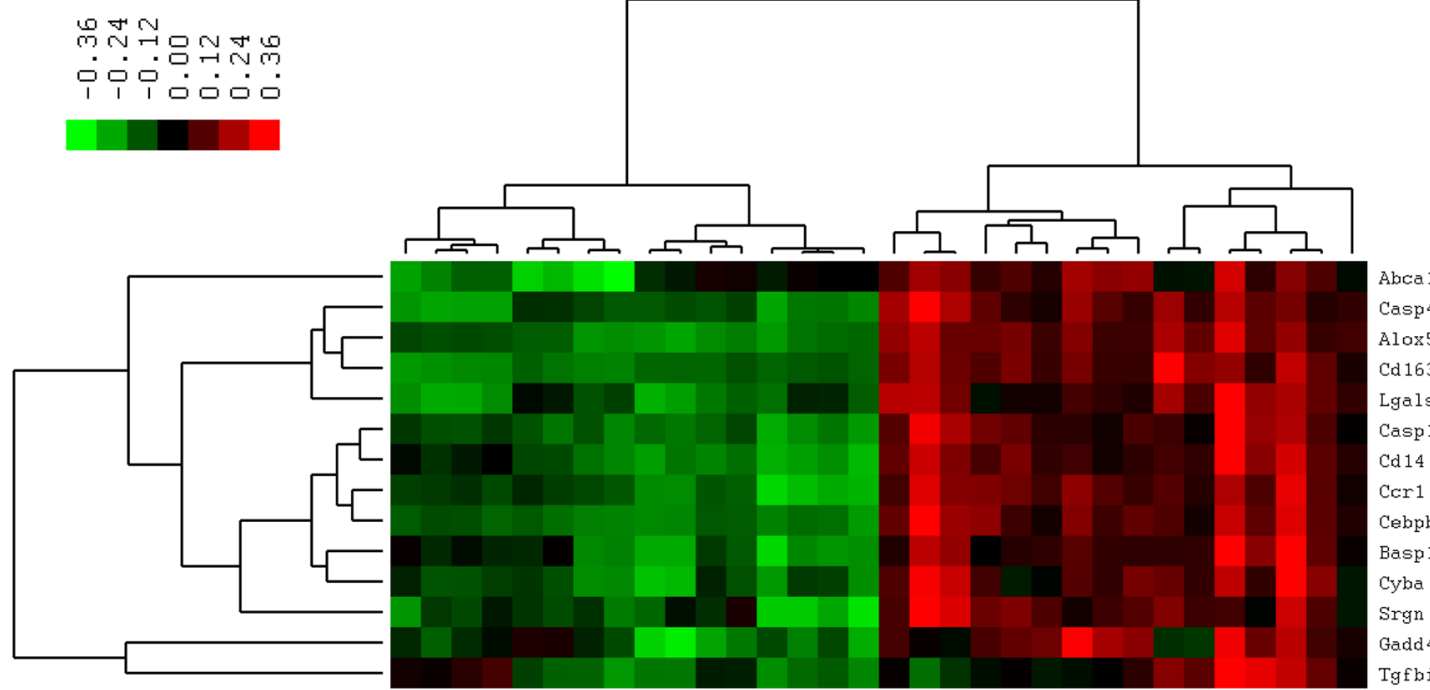

B

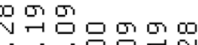

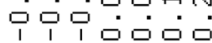

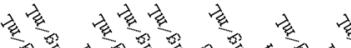

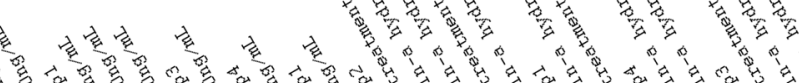

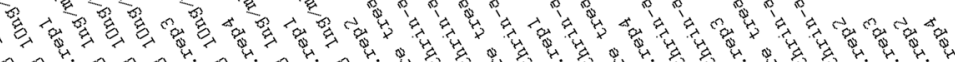

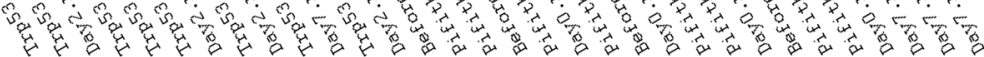

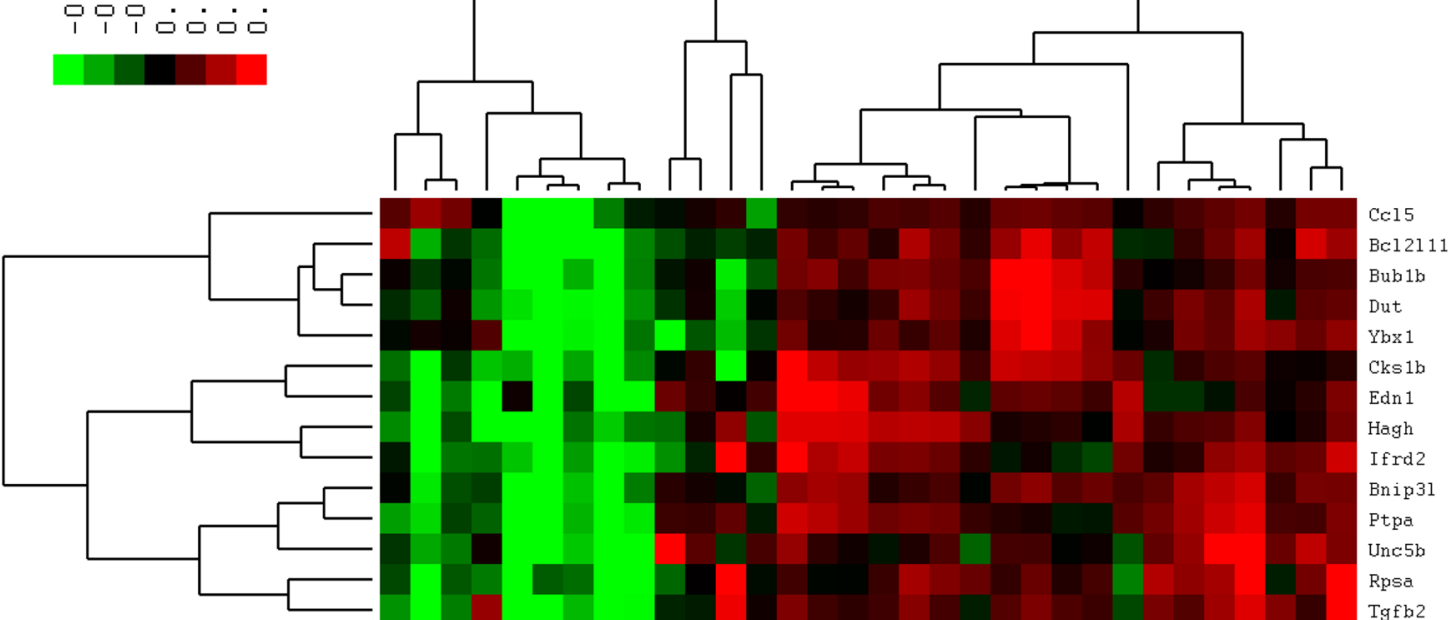

Figure 5 Hierarchical clustering of gene expression data from peripheral blood measured by real-time PCR. Peripheral blood samples were treated in vitro with two different doses of recombinant TGFB1 and p53 protein ( $1 \mathrm{ng} / \mathrm{mL}$ and $10 \mathrm{ng} / \mathrm{mL}$, panel A) and TGFB1 and TRP53 inhibitors $(0.1 \mu \mathrm{mol} / \mathrm{mL}$ and $0.5 \mu \mathrm{mol} / \mathrm{mL}$, panel B). Color codes of yellow, black, and blue represent high, average, and low expression levels, respectively, across the treatments shown. 

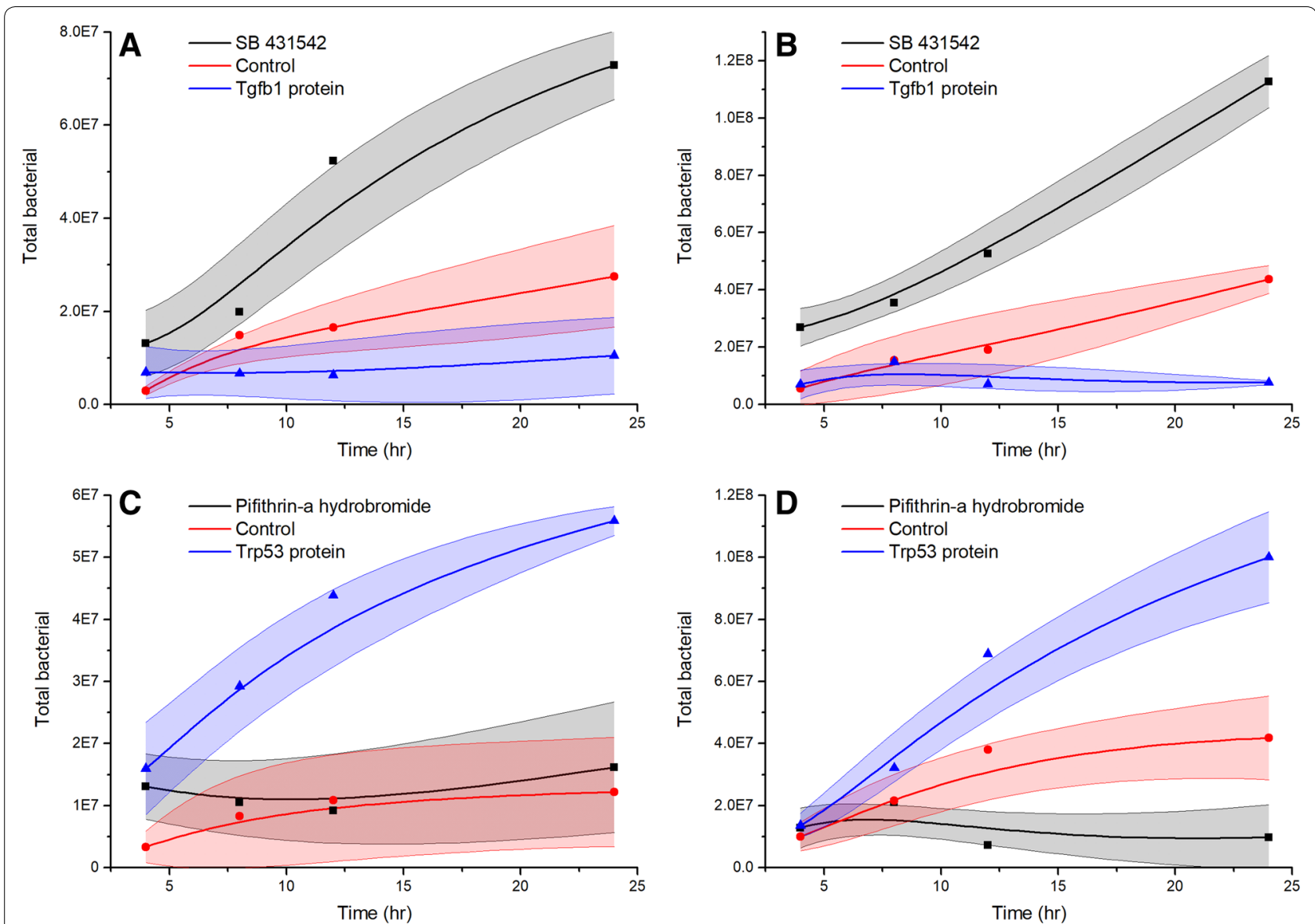

Figure 6 Intracellular growth of Salmonella enterica serovar Typhimurium strain LT2 in macrophages. Macrophages were first treated with recombinant protein or protein inhibitor, followed by infection with Salmonella bacteria, incubation for $2 \mathrm{~h}$, treatment with gentamicin (100 $\mu \mathrm{g} /$ $\mathrm{mL}$ ) for $2 \mathrm{~h}$ to kill the extracellular bacteria, and immediate lysis or incubation for an additional 8, 12, or $24 \mathrm{~h}$. Line graphs show the intracellular Salmonella counts after the macrophages were treated with Salmonella bacteria. The filled areas represent the standard deviation of three duplicate samples. A PBMCs treated with recombinant TGFB1 or TGFB1 inhibitor; B murine macrophages (RAW 264.7) treated with recombinant TGFB1 or TGFB1 inhibitor; C PBMCs treated with recombinant TRP53 or TRP53 inhibitor; D murine macrophages (RAW 264.7) treated with recombinant TRP53 or TRP53 inhibitor.

\section{Genes with decreased expression in Salmonella} Typhimurium challenge associated with ribosome function A clearly intriguing result is the gene Clusters D, E, and F, which are mostly downregulated upon inoculation with Salmonella and were identified as differentially expressed in pig peripheral blood (Figure 2). Many of the over-represented terms in this set of genes are related to ribosomes and RNA translation. The ribosome translates genetic information into peptides through several steps including initiation, elongation, termination, and circulation [61]. Interestingly, the translation elongation, translation initiation, and translation termination were all significantly over-represented in Clusters E and F. The significantly enriched regulators that have the highest number of targets are TNF, TGFB1, TRP53, and MAKP14. The roles of TNF and MAKP14 in Salmonella infection are relatively clear whereas other regulators such TGFB1 and TRP53 are not. It would be quite interesting to explore the role of these regulators in Salmonella colonization, as the decreased target gene expression of these regulators indicates an important mechanism of Salmonella bacteria regulating the host gene expression in animals.

\section{TGFB1 and TRP53 regulate intracellular Salmonella replication in pig macrophages}

The Salmonella intracellular replication assay indicated that TGFB1 can inhibit Salmonella replication and that TRP53 can promote Salmonella replication. TRP53 is a tumor suppressor gene known to balance cell survival and death in response to a variety of intrinsic and extrinsic stress signals [14, 15]. In response to Salmonella 
challenge, the TRP53 serum level was increased. Upregulation of TRP53 may lead to either cell-cycle arrest or apoptosis [62, 63]. Viral infections have also been shown to affect TRP53 activity by inducing type 1 IFN-mediated TRP53 mRNA upregulation [64]. On the other hand, TRP53 activation enhances IFN signaling [65]. During Salmonella infection, we observed both an increase in IFN secretion and enhanced TRP53 expression as well as TNF production. TRP53 can direct E2f2-mediated growth arrest involving the target gene GADD45 [66]. GADD45 was upregulated in Salmonella challenged pigs (6.8 fold for $2 \mathrm{dpi} / \mathrm{d} 0,5.4$ fold for $7 \mathrm{dpi} / \mathrm{d} 0$ ), which further supports the hypothesis that after Salmonella inoculation, cells are maintained in a cell-cycle arrested state. It has been documented that other bacterial pathogens have elaborate sophisticated mechanisms to block cell-cycle progression favoring conditions for colonization and dissemination [13, 67]. Here, we showed that TRP53 expression is affected by Salmonella challenge in peripheral blood and that TRP53 treatment can promote intracellular Salmonella growth in macrophages. We speculate that its impact on Salmonella infection can be explained by favoring a cell-cycle arrested state allowing the bacteria to proliferate more successfully.

The effect of in vivo administration of recombinant TGF- $\beta 1$ on the pathogenic mechanisms involved in experimental Salmonella Typhimurium infection in mice has been reported [12]. The protective response elicited by macrophages was induced by recombinant TGF- $\beta 1$ in 2 days after experimental infection, as demonstrated by increased NO production [12]. The mice that received TGF- $\beta 1$ survived after infection and the number of bacteria recovered in the spleens and livers of TGF- $\beta 1$-treated mice after infection was significantly smaller than that found in the same organs after phosphate-buffered saline (PBS) inoculation [12]. In the present study, TGFB1 serum levels were increased in response to Salmonella challenge in pigs. Most importantly, macrophages treated with recombinant TGF- $\beta 1$ protein showed increased resistance to intracellular Salmonella growth. Upregulation of TGFB1 regulates cell proliferation, differentiation, and growth, and can modulate the expression and activation of other growth factors including IFN- $\gamma$ and TNF $[68,69]$. We speculate that its effect on resistance to Salmonella infection is explained by favoring an innate immune system activated state allowing the host to remove or kill the bacteria more rapidly. TGFB1 maintains innate immune factor expression within a range that allows inhibition of bacterial growth during infection, a situation that is beneficial to host Salmonella resistance.

Measurement of the transcriptomic response in a limited number of individuals challenged with Salmonella identified substantially different responses of major canonical immune pathways. Our gene expression data were quite extensive in the number of responsive genes. This experiment also provided significant new information for many poorly annotated transcripts in the porcine genome, as correlation of their expression pattern to the known regulatory pathways described above may be a clue to their regulation and function in porcine Salmonella infection. Combining these results, we hypothesize that much of the gene expression response in the peripheral blood of pigs after Salmonella challenge could be directly due to higher levels of IFN- $\gamma$, TNF, and TGFB1 in the bloodstream. Intriguingly, two regulators, TGFB1 and TRP53, were found to regulate a large number of genes in peripheral blood, and could also regulate intracellular Salmonella growth in macrophages. However, the detailed mechanisms underlying this observation remain to be discovered.

\section{Additional files}

Additional file 1. GEREA. Gene expression regulator enrichment analysis. Additional file 2. Gene expression data. The complete gene expression data.

Additional file 3. Differentially expressed transcripts. The full list of differentially expressed transcripts.

Additional file 4. Over-represented pathways. The significantly overrepresented pathways in cluster $A, C, D, E$, and $F$.

Additional file 5. Regulators of differentially expressed genes. Full list of regulators of differentially expressed genes.

Additional file 6. Real-time PCR primers.

Additional file 7. Real-time PCR result. Raw data and statistical results for real-time PCR.

Additional file 8. Salmonella intracellular salmonella growth assay. Details of the Salmonella intracellular salmonella growth assay.

Competing interests

The authors declare that they have no competing interests.

Authors' contributions

THH designed the study, performed the experiments and data analysis, and wrote the manuscript. MY performed bioinformatics analysis and edited the manuscript. XLH and ZZF helped conduct the pig infection experiments, and THH performed the RNA extraction. MY participated in the interpretation and discussion of results, and provided critical comments during the drafting of the manuscript. All authors read and approved the final manuscript.

Ethics approval and consent to participate

All procedures involving animals were ethical and were approved by the Animal Care and Use Committee of Hubei Province (China, YZU-2018-0031).

\section{Funding}

This project was funded by the National Natural Science Foundation of China (NSFC Grant No. 31402055), the Yangtze Youth Talents Fund (Grant No. 2015cqr12), the Yangtze Youth Fund (Grant No. 2015cqn39), and the Scientific Research Starting Foundation for Returned Overseas Chinese Scholars of the Ministry of Education of China. 


\section{Publisher's Note}

Springer Nature remains neutral with regard to jurisdictional claims in published maps and institutional affiliations.

Received: 8 August 2018 Accepted: 29 November 2018

Published online: 12 December 2018

\section{References}

1. Hendriksen RS, Vieira AR, Karlsmose S, Lo Fo Wong DM, Jensen AB, Wegener HC, Aarestrup FM (2011) Global monitoring of Salmonella serovar distribution from the World Health Organization Global Foodborne Infections Network Country Data Bank: results of quality assured laboratories from 2001 to 2007. Foodborne Pathog Dis 8:887-900

2. Gopinath S, Carden S, Monack D (2012) Shedding light on Salmonella carriers. Trends Microbiol 20:320-327

3. Bearson SM, Allen HK, Bearson BL, Looft T, Brunelle BW, Kich JD, Tuggle CK, Bayles DO, Alt D, Levine UY, Stanton TB (2013) Profiling the gastrointestinal microbiota in response to Salmonella: low versus high Salmonella shedding in the natural porcine host. Infect Genet Evol 16:330-340

4. Chiou CS, Wei HL, Mu JJ, Liao YS, Liang SY, Liao CH, Tsao CS, Wang SC (2013) Salmonella enterica serovar Typhi variants in long-term carriers. J Clin Microbiol 51:669-672

5. Forbes JR, Gros P (2001) Divalent-metal transport by NRAMP proteins at the interface of host-pathogen interactions. Trends Microbiol 9:397-403

6. Aderem A, Ulevitch RJ (2000) Toll-like receptors in the induction of the innate immune response. Nature 406:782-787

7. Jack RS, Fan X, Bernheiden M, Rune G, Ehlers M, Weber A, Kirsch G, Mentel R, Furll B, Freudenberg M, Schmitz G, Stelter F, Schutt C (1997) Lipopolysaccharide-binding protein is required to combat a murine Gram-negative bacterial infection. Nature 389:742-745

8. Nathan C, Shiloh MU (2000) Reactive oxygen and nitrogen intermediates in the relationship between mammalian hosts and microbial pathogens. Proc Natl Acad Sci USA 97:8841-8848

9. Fiers W (1991) Tumor necrosis factor. Characterization at the molecular, cellular and in vivo level. FEBS Lett 285:199-212

10. Dorman SE, Holland SM (2000) Interferon-gamma and interleukin-12 pathway defects and human disease. Cytokine Growth Factor Rev 11:321-333

11. Jouanguy E, Doffinger R, Dupuis S, Pallier A, Altare F, Casanova JL (1999) IL-12 and IFN-gamma in host defense against mycobacteria and salmonella in mice and men. Curr Opin Immunol 11:346-351

12. Galdiero M, Marcatili A, Cipollaro de l'Ero G, Nuzzo I, Bentivoglio C, Romano Carratelli M, Galdiero C (1999) Effect of transforming growth factor beta on experimental Salmonella typhimurium infection in mice. Infect Immun 67:1432-1438

13. Khan R, Sancho-Shimizu V, Prendergast C, Roy MF, Loredo-Osti JC, Malo D (2012) Refinement of the genetics of the host response to Salmonella infection in MOLF/Ei: regulation of type 1 IFN and TRP3 pathways by Ity2. Genes Immun 13:175-183

14. Zwang Y, Oren M, Yarden Y (2012) Consistency test of the cell cycle: roles for p53 and EGR1. Cancer Res 72:1051-1054

15. Apostolidis PA, Lindsey S, Miller WM, Papoutsakis ET (2012) Proposed megakaryocytic regulon of p53: the genes engaged to control cell cycle and apoptosis during megakaryocytic differentiation. Physiol Genomics 44:638-650

16. Burkey TE, Skjolaas KA, Dritz SS, Minton JE (2009) Expression of porcine Toll-like receptor 2,4 and 9 gene transcripts in the presence of lipopolysaccharide and Salmonella enterica serovars Typhimurium and Choleraesuis. Vet Immunol Immunopathol 130:96-101

17. Meurens F, Berri M, Auray G, Melo S, Levast B, Virlogeux-Payant I, Chevaleyre C, Gerdts V, Salmon H (2009) Early immune response following Salmonella enterica subspecies enterica serovar Typhimurium infection in porcine jejunal gut loops. Vet Res 40:5

18. Skjolaas KA, Burkey TE, Dritz SS, Minton JE (2006) Effects of Salmonella enterica serovars Typhimurium (ST) and Choleraesuis (SC) on chemokine and cytokine expression in swine ileum and jejunal epithelial cells. Vet Immunol Immunopathol 111:199-209
19. Hyland KA, Kohrt L, Vulchanova L, Murtaugh MP (2006) Mucosal innate immune response to intragastric infection by Salmonella enterica serovar Choleraesuis. Mol Immunol 43:1890-1899

20. Burkey TE, Skjolaas KA, Dritz SS, Minton JE (2007) Expression of toll-like receptors, interleukin 8 , macrophage migration inhibitory factor, and osteopontin in tissues from pigs challenged with Salmonella enterica serovar Typhimurium or serovar Choleraesuis. Vet Immunol Immunopathol 115:309-319

21. Uthe JJ, Stabel TJ, Zhao SH, Tuggle CK, Bearson SM (2006) Analysis of porcine differential gene expression following challenge with Salmonella enterica serovar Choleraesuis using suppression subtractive hybridization. Vet Microbiol 114:60-71

22. Collado-Romero M, Arce C, Ramirez-Boo M, Carvajal A, Garrido JJ (2010) Quantitative analysis of the immune response upon Salmonella typhimurium infection along the porcine intestinal gut. Vet Res 41:23

23. Dvorak CM, Hirsch GN, Hyland KA, Hendrickson JA, Thompson BS, Rutherford MS, Murtaugh MP (2006) Genomic dissection of mucosal immunobiology in the porcine small intestine. Physiol Genomics 28:5-14

24. Zhao SH, Kuhar D, Lunney JK, Dawson H, Guidry C, Uthe JJ, Bearson SM, Recknor J, Nettleton D, Tuggle CK (2006) Gene expression profiling in Salmonella Choleraesuis-infected porcine lung using a long oligonucleotide microarray. Mamm Genome 17:777-789

25. Huang TH, Uthe JJ, Bearson SM, Demirkale CY, Nettleton D, Knetter S, Christian C, Ramer-Tait AE, Wannemuehler MJ, Tuggle CK (2011) Distinct peripheral blood RNA responses to Salmonella in pigs differing in Salmonella shedding levels: intersection of IFNG. TLR and miRNA pathways. PLoS One 6:e28768

26. Lim JS, Na HS, Lee HC, Choy HE, Park SC, Han JM, Cho KA (2009) Caveolae-mediated entry of Salmonella typhimurium in a human M-cell model. Biochem Biophys Res Commun 390:1322-1327

27. Wang KC, Huang CH, Huang CJ, Fang SB (2016) Impacts of Salmonella enterica serovar Typhimurium and its speG gene on the transcriptomes of in vitro M cells and Caco-2 cells. PLoS One 11:e0153444

28. Biozzi G, Howard JG, Halpern BN, Stiffel C, Mouton D (1960) The kinetics of blood clearance of isotopically labelled Salmonella entertidis by the reticulo-endothelial system in mice. Immunology 3:74-89

29. Dunlap NE, Benjamin WH Jr, McCall RD Jr, Tilden AB, Briles DE (1991) A 'safe-site' for Salmonella typhimurium is within splenic cells during the early phase of infection in mice. Microb Pathog 10:297-310

30. Tomas A, Fernandes LT, Sanchez A, Segales J (2010) Time course differential gene expression in response to porcine circovirus type 2 subclinical infection. Vet Res 41:12

31. Tuggle CK, Bearson SM, Uthe JJ, Huang TH, Couture OP, Wang YF, Kuhar D, Lunney JK, Honavar V (2010) Methods for transcriptomic analyses of the porcine host immune response: application to Salmonella infection using microarrays. Vet Immunol Immunopathol 138:280-291

32. Shi Z, Sun J, Guo H, Tu C (2009) Genomic expression profiling of peripheral blood leukocytes of pigs infected with highly virulent classical swine fever virus strain Shimen. J Gen Virol 90:1670-1680

33. Li J, Yu YJ, Feng L, Cai XB, Tang HB, Sun SK, Zhang HY, Liang JJ, Luo TR (2010) Global transcriptional profiles in peripheral blood mononuclear cell during classical swine fever virus infection. Virus Res 148:60-70

34. Gladue DP, Zhu J, Holinka LG, Fernandez-Sainz I, Carrillo C, Prarat MV, O'Donnell V, Borca MV (2010) Patterns of gene expression in swine macrophages infected with classical swine fever virus detected by microarray. Virus Res 151:10-18

35. Renson $P$, Blanchard $Y$, Le Dimna M, Felix $H$, Cariolet $R$, Jestin $A$, Le Potier MF (2010) Acute induction of cell death-related IFN stimulated genes (ISG) differentiates highly from moderately virulent CSFV strains. Vet Res 41:7

36. Moser RJ, Reverter A, Lehnert SA (2008) Gene expression profiling of porcine peripheral blood leukocytes after infection with Actinobacillus pleuropneumoniae. Vet Immunol Immunopathol 121:260-274

37. Gao Y, Flori L, Lecardonnel J, Esquerre D, Hu ZL, Teillaud A, Lemonnier G, Lefevre F, Oswald IP, Rogel-Gaillard C (2010) Transcriptome analysis of porcine PBMCs after in vitro stimulation by LPS or PMA/ionomycin using an expression array targeting the pig immune response. BMC Genomics 11:292 
38. Ponsuksili S, Murani E, Wimmers K (2008) Porcine genome-wide gene expression in response to tetanus toxoid vaccine. Dev Biol 132:185-195

39. Clapperton M, Diack AB, Matika O, Glass EJ, Gladney CD, Mellencamp MA, Hoste A, Bishop SC (2009) Traits associated with innate and adaptive immunity in pigs: heritability and associations with performance under different health status conditions. Genet Sel Evol 41:54

40. Crawley AM, Mallard B, Wilkie BN (2005) Genetic selection for high and low immune response in pigs: effects on immunoglobulin isotype expression. Vet Immunol Immunopathol 108:71-76

41. Edfors-Lilja I, Wattrang E, Magnusson U, Fossum C (1994) Genetic variation in parameters reflecting immune competence of swine. Vet Immunol Immunopathol 40:1-16

42. Edfors-Lilja I, Wattrang E, Andersson L, Fossum C (2000) Mapping quantitative trait loci for stress induced alterations in porcine leukocyte numbers and functions. Anim Genet 31:186-193

43. Edfors-Lilja I, Wattrang E, Marklund L, Moller M, Andersson-Eklund L, Andersson L, Fossum C (1998) Mapping quantitative trait loci for immune capacity in the pig. J Immunol 161:829-835

44. Wattrang $E$, Almqvist M, Johansson A, Fossum C, Wallgren P, Pielberg G, Andersson L, Edfors-Lilja I (2005) Confirmation of QTL on porcine chromosomes 1 and 8 influencing leukocyte numbers, haematological parameters and leukocyte function. Anim Genet 36:337-345

45. Van Diemen PM, Kreukniet MB, Galina L, Bumstead N, Wallis TS (2002) Characterisation of a resource population of pigs screened for resistance to salmonellosis. Vet Immunol Immunopathol 88:183-196

46. Galina-Pantoja L, Siggens K, van Schriek MG, Heuven HC (2009) Mapping markers linked to porcine salmonellosis susceptibility. Anim Genet 40:795-803

47. Uthe JJ, Wang Y, Qu L, Nettleton D, Tuggle CK, Bearson SM (2009) Correlating blood immune parameters and a CCT7 genetic variant with the shedding of Salmonella enterica serovar Typhimurium in swine. Vet Microbiol 135:384-388

48. Langmead B, Trapnell C, Pop M, Salzberg SL (2009) Ultrafast and memoryefficient alignment of short DNA sequences to the human genome. Genome Biol 10:R25

49. O'Leary NA, Wright MW, Brister JR, Ciufo S, Haddad D, McVeigh R, Rajput B, Robbertse B, Smith-White B, Ako-Adjei D, Astashyn A, Badretdin A, Bao Y, Blinkova O, Brover V, Chetvernin V, Choi J, Cox E, Ermolaeva O, Farrell CM, Goldfarb T, Gupta T, Haft D, Hatcher E, Hlavina W, Joardar VS, Kodali VK, Li W, Maglott D, Masterson P et al (2016) Reference sequence (RefSeq) database at NCBI: current status, taxonomic expansion, and functional annotation. Nucleic Acids Res 44:D733-745

50. Ritchie ME, Phipson B, Wu D, Hu Y, Law CW, Shi W, Smyth GK (2015) limma powers differential expression analyses for RNA-sequencing and microarray studies. Nucleic Acids Res 43:e47

51. Barrett T, Wilhite SE, Ledoux P, Evangelista C, Kim IF, Tomashevsky M, Marshall KA, Phillippy KH, Sherman PM, Holko M, Yefanov A, Lee H, Zhang N, Robertson CL, Serova N, Davis S, Soboleva A (2013) NCBI GEO: archive for functional genomics data sets-update. Nucleic Acids Res 41:D991-995

52. Benjamini Y, Yekutieli D (2005) Quantitative trait loci analysis using the false discovery rate. Genetics 171:783-790

53. Wurfel MM, Park WY, Radella F, Ruzinski J, Sandstrom A, Strout J, Bumgarner RE, Martin TR (2005) Identification of high and low responders to lipopolysaccharide in normal subjects: an unbiased approach to identify modulators of innate immunity. J Immunol 175:2570-2578
54. de Hoon MJ, Imoto S, Nolan J, Miyano S (2004) Open source clustering software. Bioinformatics 20:1453-1454

55. Lynn DJ, Winsor GL, Chan C, Richard N, Laird MR, Barsky A, Gardy JL, Roche FM, Chan TH, Shah N, Lo R, Naseer M, Que J, Yau M, Acab M, Tulpan D, Whiteside MD, Chikatamarla A, Mah B, Munzner T, Hokamp K, Hancock RE, Brinkman FS (2008) InnateDB: facilitating systems-level analyses of the mammalian innate immune response. Mol Syst Biol 4:218

56. Yao M, Gao W, Tao H, Yang J, Liu G, Huang T (2016) Regulation signature of miR-143 and miR-26 in porcine Salmonella infection identified by binding site enrichment analysis. Mol Genet Genomics 291:789-799

57. Finlay BB, Falkow S (1988) Comparison of the invasion strategies used by Salmonella cholerae-suis, Shigella flexneri and Yersinia enterocolitica to enter cultured animal cells: endosome acidification is not required for bacterial invasion or intracellular replication. Biochimie 70:1089-1099

58. Saha B, Jyothi Prasanna S, Chandrasekar B, Nandi D (2010) Gene modulation and immunoregulatory roles of interferon gamma. Cytokine 50:1-14

59. Hu X, Chung AY, Wu I, Foldi J, Chen J, Ji JD, Tateya T, Kang YJ, Han J, Gessler M, Kageyama R, Ivashkiv LB (2008) Integrated regulation of toll-like receptor responses by notch and interferon-gamma pathways. Immunity 29:691-703

60. Vazquez-Torres A, Fantuzzi G, Edwards CK 3rd, Dinarello CA, Fang FC (2001) Defective localization of the NADPH phagocyte oxidase to Salmonella-containing phagosomes in tumor necrosis factor p55 receptor-deficient macrophages. Proc Natl Acad Sci USA 98:2561-2565

61. Buskirk AR, Green R (2017) Ribosome pausing, arrest and rescue in bacteria and eukaryotes. Philos Trans R Soc Lond B Biol Sci 372:20160183

62. Harris SL, Levine AJ (2005) The p53 pathway: positive and negative feedback loops. Oncogene 24:2899-2908

63. Schlereth K, Charles JP, Bretz AC, Stiewe T (2010) Life or death: p53induced apoptosis requires DNA binding cooperativity. Cell Cycle 9:4068-4076

64. Takaoka A, Hayakawa S, Yanai H, Stoiber D, Negishi H, Kikuchi H, Sasaki S, Imai K, Shibue T, Honda K, Taniguchi T (2003) Integration of interferonalpha/beta signalling to $\mathrm{p} 53$ responses in tumour suppression and antiviral defence. Nature 42:516

65. Munoz-Fontela C, Macip S, Martinez-Sobrido L, Brown L, Ashour J, Garcia-Sastre A, Lee SW, Aaronson SA (2008) Transcriptional role of p53 in interferon-mediated antiviral immunity. J Exp Med 205:1929-1938

66. Sharma N, Timmers C, Trikha P, Saavedra HI, Obery A, Leone G (2006) Control of the p53-p21CIP1 Axis by E2f1, E2f2, and E2f3 is essential for G1/S progression and cellular transformation. J Biol Chem 281:36124-36131

67. Fehri LF, Rechner C, Janssen S, Mak TN, Holland C, Bartfeld S, Bruggemann $H$, Meyer TF (2009) Helicobacter pylori-induced modification of the histone $\mathrm{H} 3$ phosphorylation status in gastric epithelial cells reflects its impact on cell cycle regulation. Epigenetics 4:577-586

68. Tauriello DVF, Palomo-Ponce S, Stork D, Berenguer-Llergo A, BadiaRamentol J, Iglesias M, Sevillano M, Ibiza S, Canellas A, HernandoMomblona X, Byrom D, Matarin JA, Calon A, Rivas El, Nebreda AR, Riera A, Attolini CS, Batlle E (2018) TGFbeta drives immune evasion in genetically reconstituted colon cancer metastasis. Nature 554:538-543

69. Yu X, Buttgereit A, Lelios I, Utz SG, Cansever D, Becher B, Greter M (2017) The cytokine TGF-beta promotes the development and homeostasis of alveolar macrophages. Immunity 47:903-912.e904

Ready to submit your research? Choose BMC and benefit from:

- fast, convenient online submission

- thorough peer review by experienced researchers in your field

- rapid publication on acceptance

- support for research data, including large and complex data types

- gold Open Access which fosters wider collaboration and increased citations

- maximum visibility for your research: over $100 \mathrm{M}$ website views per year

At BMC, research is always in progress.

Learn more biomedcentral.com/submissions 